\title{
UPAYA MENINGKATKAN PRESTASI LOMPAT JAUH GAYA JONGKOK MENGGUNAKAN ALAT BANTU PADA ANAK KELAS V SDN 2 LABAN TAHUN PELAJARAN 2017/2018
}

\author{
Hari Sutalhadi \\ SDN 2 Laban, Gresik \\ sutalhadisd2laban@gmail.com
}

\begin{abstract}
ABSTRAK
Siswa kelas V SDN 2 Laban mengalami kesulitan dalam melakukan teknik lompat jauh gaya jongkok. Sebagian besar siswa baru menguasai cara melompat. Mereka belum mampu melakukan gerakan secara keseluruhan terbukti dari hasil evaluasi, dari 25 siswa kelas $\mathrm{V}$, baru 15 siswa (33,3\%) yang dapat melakukan teknik lompat jauh gaya jongkok.

Penggunaan penggunaan alat bantu bok kardus dan gawang aman terbukti sangat membantu peningkatan hasil belajar siswa. Siswa yang takut melakukan lompatan menjadi tidak takut, siswa juga belajar dengan penuh percaya diri, semangat, disiplin, jujur, dan penuh tanggung jawab. Pada pratindakan 5 anak (33,3\%) telah mencapai nilai KKM, pada siklus I 10 anak (66,7\%), kemudian pada siklus II 25 anak (100\%) telah mencapai nilai KKM. Dari pratindakan ke siklus I jika dibandingkan terlihat hasil belajar siswa mengalami kenaikan 5 anak $(33,3 \%)$, yaitu dari 15 siswa menjadi 10 siswa dan dari siklus I ke siklus II juga mengalami kenaikan 15 anak (33,3\%), yaitu dari 10 siswa menjadi 15 siswa. Berdasarkan hasil tersebut disimpulkan bahwa hasil belajar lompat jauh gaya jongkok siswa melalui penggunaan alat bantu gawang aman telah mencapai kategori sangat baik.
\end{abstract}

Katakunci : Lompat Jauh, Gaya jongkok, Alat Bantu

\section{ABSTRACT}

The fifth grade student at SDN 2 Laban had difficulty in doing squat style long jump techniques. Most students just master how to jump. They have not been able to make the overall movement as evidenced by the results of the evaluation, out of 25 students in class $\mathrm{V}$, only 15 students (33.3\%) can do the squat style long jump technique.

The use of the use of safe boxes and safe boxes proved to be very helpful in improving student learning outcomes. Students who are afraid to make a leap are not afraid, students also learn with confidence, enthusiasm, discipline, honesty, and full of responsibility. In the pre-action 5 children (33.3\%) had reached the KKM score, in the first cycle 10 children (66.7\%), then in the second cycle 25 children (100\%) had reached the KKM score. From the pre-action to the first cycle when compared it is seen that student learning outcomes have increased by 5 children (33.3\%), namely from 15 students to 10 students and from cycle I to cycle II also experienced an increase of 15 children (33.3\%), namely from 10 students to 15 students. Based on these results it was concluded that the learning outcomes of squatting long jumps of students through the use of safe goalkeeper tools had reached a very good category.

Keywords: Long Jump, Squat Style, Tools

\section{PENDAHULUAN}

Pendidikan jasmani pada dasarnya merupakan bagian integral dari sistem pendidikan secara keseluruhan yang bertujuan untuk mengembangkan aspek kesehatan. Pendidikan jasmani merupakan alat untuk mencapai pendidikan jasmani 
dan olah raga di sekolah sebelum mendapatkan format yang tepat, karena selalu menyesuaikan perubahan kurikulum.

Proses

pembelajaran

pendidikan jasmani, olah raga, dan

kesehatan di sekolah dasar mengutamakan kesehatan mental dan kesegaran jasmani, untuk mencari calon atlet harus benarbenar sesuai dengan cabangnya (Sarayin, 1998).

Keadaan siswa SDN 2 Laban Kecamatan Menganti Kabupaten Gresik pada dasarnya senang terhadap pembelajaran pendidikan jasmani dan olah raga, terutama pada cabang permainan. Pada cabang atletik, anak kurang menyenangi dengan alasan tidak menyenangkan. Karena pembelajaran atletik di SDN 2 Laban Kecamatan Menganti Kabupaten Gresik kurang mendapat tanggapan yang positif dari para siswa, maka prestasi pada cabang atletik khusus pada nomor lompat jauh belum bisa optimal. Hal ini bisa terjadi karena beberapa faktor penyebab yaitu: (1) Terbatasnya kemampuan guru pendidikan jasmani, (2) Terbatasnya alat bantu dalam proses pembelajaran pendidikan jasmani.

Terbatasnya kemampuan guru pendidikan jasmani di SD akan berakibat pada proses pembelajaran yang kurang berhasil. Karena guru kurang mampu dalam melaksanakan profesinya secara profesional, dan kurang berhasil dalam mengajar dan mendidik siswa secara sistematik. Karena dalam pembelajaran pendidikan jasmani diberikan gerakan yang sistematik untuk mengembangkan kemampuan dan keterampilan siswa secara menyeluruh baik fisik, mental, maupun intelektual.

Gaya yang dipakai guru dalam mengajar praktek pendidikan jasmani juga monoton, yaitu hanya menggunakan satu gaya mengajar. Sehingga situasi pembelajaran yang dirasakan oleh siswa terasa membosankan. Dan juga metode praktik ditekankan pada latihanlatihan berdasarkan perintah yang ditentukan oleh guru. Latihan-latihan tersebut tidak dilakukan sesuai inisiatif dari siswa itu sendiri. Dalam hal ini guru cenderung menggunakan pendekatan pembelajaran yang mengarah pada prestasi. Sehingga dalam prosesnya berbeda dari pembelajaran penjas itu sendiri, yaitu tujuan utama bukan proses dalam peraturan, ukuran lapangan, maupun alat. Proses pembelajaran seperti ini akan membuat siswa kurang senang untuk melaksanakannya, bahkan merasa bosan dan yang lebih fatal siswa merasa frustasi untuk melaksanakan tugas dari guru.

Pembelajaran di SDN 2 Laban Kecamatan Menganti Kabupaten Gresik siswa kelas V tersebut mengalami kesulitan dalam melakukan teknik lompat jauh gaya jongkok. Sebagian besar siswa baru menguasai cara melompat. Mereka 
belum mampu melakukan gerakan secara keseluruhan terbukti dari hasil evaluasi, dari siswa kelas $\mathrm{V}$ yang berjumlah 15 anak yang terdiri dari 10 siswa laki-laki dan 15 siswa perempuan, baru 15 siswa (33,3\%) yang dapat melakukan teknik lompat jauh gaya jongkok dan sisanya masih 10 siswa $(66,7 \%)$ yang masih belum menguasai teknik lompat jauh gaya jongkok.

Salah satu pendekatan dalam pembelajaran yang dapat digunakan dalam hal ini adalah pendekatan pembelajaran dengan menggunakan alat bantu berupa bok kardus dan gawang aman, yaitu suatu pendekatan pembelajaran untuk membantu siswa untuk mempelajari keterampilan dasar dalam mempelajari teknik dasar lompat jauh.

Model pembelajaran dengan pendekatan alat bantu dirancang dengan teliti agar bisa mengembangkan belajar siswa dan dilakukan dengan baik dan dapat dipelajari langkah demi langkah. Alat bantu berupa bok kardus dan gawang aman dalam pelaksanaan pembelajaran diharapkan membuat siswa lebih mudah menerima materi ajar, dan dapat mengubah suasana menjadi lebih rileks dan menyenangkan bahkan siswa saling berlomba memakai dan melewati alat bantu tersebut. Hal ini akan membantu meningkatkan motivasi siswa terhadap materi lompat jauh gaya jongkok.

\section{Rumusan Masalah}

Berdasarkan latar belakang dan identifikasi masalah, maka permasalahan yang menjadi pokok penelitian adalah bagaimanakah penggunaan alat bantu dapat meningkatkan hasil belajar lompat jauh gaya jongkok pada siswa kelas $\mathrm{V}$ SDN 2 Laban Kecamatan Menganti Kabupaten Gresik Tahun Pelajaran 2017/2018?

\section{Tujuan Penelitian}

Penelitian ini bertujuan untuk meningkatkan hasil belajar lompat jauh gaya jongkok melalui penggunaan alat bantu pada siswa kelas V SDN 2 Laban Kecamatan Menganti Kabupaten Gresik Tahun Ajaran 2017/2018.

\section{Manfaat Penelitian}

Manfaat yang diharapkan dari penelitian ini adalah:

1. Bagi Guru

a. Meningkatkan kreatifitas guru dalam membuat dan mengembangkan alat bantu pembelajaran.

b. Bahan masukan bagi guru dalam memilih alternatif pembelajaran.

c. Meningkatkan kualitas guru secara profesional dalam pengembangan alat bantu.

2. Bagi Siswa

a. Motivasi siswa untuk aktif dan antusias dalam mengikuti pembelajaran Penjaskes, 
sehingga tercipta pembelajaran yang menyenangkan.

b. Meningkatkan minat dan kemampuan lompat jauh gaya jongkok serta mendukung prestasi.

3. Bagi Sekolah
a. Sebagai pedoman dan pengetahuan pada pembelajaran pendidikan jasmani, olahraga, dan kesehatan.

b. Sebagai data inventaris siswa yang berprestasi dalam cabang atletik.

\section{METODOLOGI PENELITIAN}

\section{Tempat dan Waktu Penelitian}

Penelitian dilaksanakan di SDN

2 Laban, Kecamatan Menganti, Kabupaten Gresik. Lokasi SDN 2 Laban Kecamatan Menganti Kabupaten Gresik sangat strategis karena terletak di jalan raya dan terletak di tengah-tengah pemukiman penduduk sehingga mudah dijangkau oleh para siswanya.

Sarana dan prasarananya sangat mendukung untuk dilakukan penelitian tindakan kelas. Halaman sekolah sangat luas, sehingga sangat mendukung pembelajaran penjasorkes. Perpustakaan telah menyediakan berbagai buku sumber sebagai pendukung dan sumber data penelitian. Sarana olahraga seperti peralatan olahraga, kit atletik, dan lain-lain tersedia cukup lengkap. Lapangan olahraga juga sangat memadai untuk pelaksanaan penelitian tentang lompat jauh gaya jongkok.

Penelitian ini dilaksanakan bulan Maret 2018. Kegiatan penelitian ini meliputi persiapan, pelaksanaan, dan penyusunan laporan. Kegiatan persiapan meliputi observasi, identifikasi masalah, penentuan tindakan, Pengajuan judul, penyusunan proposal, dan Pengajuan ijin penelitian. Kegiatan pelaksanaan meliputi seminar proposal dan pengumpulan data penelitian. Penyusunan laporan meliputi penulisan laporan dan ujian skripsi. Untuk lebih jelasnya, berikut tabel jadwal penelitian tindakan kelas materi pembelajaran lompat jauh gaya jongkok melalui penggunaan alat bantu bok kardus dan gawang aman di SDN 2 Laban Kecamatan Menganti Kabupaten Gresik.

\section{Subjek Penelitian}

Subyek penelitian ini adalah siswa kelas V SDN 2 Laban Kecamatan Menganti Kabupaten Gresik Kecamatan Kabupaten tahun pelajaran 2017/2018. Seluruh siswa kelas V SDN 2 Laban Kecamatan Menganti Kabupaten Gresik dijadikan subyek penelitian. Jumlah subyek dalam penelitian ini yaitu 25 orang siswa yang terdiri dari 10 siswa laki-laki dan 15 siswa perempuan.

Siswa kelas V SDN 2 Laban Kecamatan Menganti Kabupaten Gresik mayoritas berasal dari keluarga petani, oleh karena itu sebagian waktunya di rumah 
digunakan untuk membantu orang tua, sehingga mereka jarang melakukan latihan olahraga selama di rumah. Apalagi untuk materi lompat jauh, mereka, para siswa masih sangat asing, artinya mereka hanya akrab dengan olahraga permainan seperti sepak bola, sehingga materi lompat jauh seolah-olah dikesampingkan.

\section{Data dan Sumber Data}

Data dan sumber data penelitian ini meliputi jenis data dan sumber data. Jenis data penelitian ini berupa motivasi belajar siswa dan kemampuan siswa dalam melakukan lompat jauh gaya jongkok. Sumber data yang digunakan dalam Penelitian Tindakan Kelas ini adalah sebagai berikut:

1. Siswa, sebagai subyek untuk mendapatkan data tentang lompat jauh gaya jongkok.

2. Guru, sebagai kolaborator, untuk melihat tingkat keberhasilan penerapan pembelajaran lompat jauh gaya jongkok dengan penggunaan alat bantu pada siswa kelas V SDN 2 Laban Kecamatan Menganti Kabupaten Gresik Tahun Pelajaran 2017/2018.

3. Hasil tes formatif berupa data kuantitatif.

4. Hasil pengamatan keaktifan siswa berupa data kualitatif.

\section{Pengumpulan Data}

Data yang diperlukan dalam penelitian tindakan kelas ini berupa hasil wawancara dengan subyek penelitian yaitu siswa kelas $\mathrm{V}$ dan sumber data yaitu guru, dan pengumpulan catatan hasil pengamatan. Hasil pengamatan tersebut dikumpulkan melalui pengamatan, hasil tes siswa dan angket. Pemberian dan pengisian angket oleh siswa dilaksanakan pada pertemuan ke dua (siklus terakhir), setelah tindakan selesai.

\section{Uji Validitas Data}

Data yang sudah terkumpul merupakan modal awal yang sangat berharga dalam penelitian ini, dari data yang terkumpul akan dilakukan analisis yang selanjutnya dipakai sebagai bahan masukan untuk penarikan kesimpulan. Melihat begitu besarnya posisi data, maka keabsahan data yang terkumpul menjadi sangat vital.

Keabsahan data itu dikenal sebagai validitas data, sebagaimana dijelaskan Alwasilah (2008: 170) bahwa tantangan bagi segala jenis penelitian pada akhirnya adalah terwujudnya produksi ilmu pengetahuan yang valid, sahih, benar, dan beretika. Validitas data penelitian tindakan kelas ini diuji dengan menggunakan triangulasi, yaitu:

1. Hasil belajar lompat jauh gaya jongkok dianalisis dengan menggunakan triangulasi, yaitu dengan data yang diperoleh dari peneliti, observer, dan siswa. 
2. Keaktifan siswa dianalisis dengan menggunakan data yang diperoleh dari peneliti, observer, dan siswa.

3. Aktivitas guru dianalisis dengan menggunakan data yang diperoleh dari peneliti, observer, dan siswa.

4. Penggunaan alat bantu (bok kardus, gawang aman) dianalisis dengan menggunakan data yang diperoleh dari peneliti, observer, dan siswa.

5. Nilai hasil belajar alat bantu (bok kardus, gawang aman) sebelum tindakan divalidasi dengan triangulasi peneliti.

6. RPP, silabus, kurikulum divalidasi dengan triangulasi dokumen.

7. Emosi siswa divalidasi dengan triangulasi kartu ceria.

\section{Analisis Data}

Data yang dianalisis meliputi data kuantitatif (dengan menampilkan angka-angka sebagai ukuran prestasi), dan data kualitatif (dengan menampilkan angka sebagai perbandingan). Analisis data dilakukan dengan cara mengorganisasikan data ke dalam kategori, menjabarkan ke dalam unitunit, melakukan sintesa, menyusun ke dalam pola, memilih mana yang penting yang akan dipelajari, dan membuat kesimpulan sehingga mudah dipahami oleh orang lain (Sugiyono, 2010).

Analisis data dilakukan secara deskriptif komparatif yang bertujuan untuk membandingkan kondisi sebelum dan sesudah diadakan tindakan perbaikan pembelajaran. Menurut Rochiati (2005) Tahapan dalam tindakan menganalisis data meliputi reduksi data, penyajian data, dan penarikan kesimpulan.

Data kualitatif dianalisis dengan teknik analisis kritis, yaitu mengidentifikasi kelemahan dan kelebihan kinerja siswa dan guru selama proses penerapan tindakan. Hasil analisis tersebut menjadi bahan untuk menyusun rencana memperbaiki pelaksanaan tindakan pada siklus berikutnya.

\section{Indikator Kinerja Penelitian}

Untuk

menentukan ketercapaian tujuan, perlu dirumuskan indikator keberhasilan tindakan yang disusun secara realistik, yaitu mempertimbangkan kondisi pratindakan dan jumlah siklus tindakan yang akan dilakukan dan dapat diukur dengan jelas. Indikator kinerja penelitian ini dirumuskan sebagai berikut:

Tabel 1. Indikator Kinerja Penelitian

\begin{tabular}{|c|c|c|}
\hline Aspek yang Diukur & $\begin{array}{c}\text { Persentase } \\
\text { Siswa yang } \\
\text { Ditargetkan }\end{array}$ & Cara Mengukur \\
\hline Minat belajar siswa & $80 \%$ & $\begin{array}{l}\text { Diamati saat pembelajaran dan dihitung jumlah } \\
\text { siswa yang memfokuskan perhatiannya dalam }\end{array}$ \\
\hline
\end{tabular}




\begin{tabular}{|c|c|c|}
\hline Aspek yang Diukur & $\begin{array}{c}\text { Persentase } \\
\text { Siswa yang } \\
\text { Ditargetkan }\end{array}$ & Cara Mengukur \\
\hline & & melakukan lompat jauh gaya jongkok. \\
\hline $\begin{array}{c}\text { Keaktifan siswa dalam } \\
\text { melakukan lompat } \\
\text { jauh gaya jongkok }\end{array}$ & $80 \%$ & $\begin{array}{c}\text { Diamati saat pembelajaran dan dihitung jumlah } \\
\text { siswa yang menampakan keaktifan dalam } \\
\text { melakukan lompat jauh gaya jongkok. }\end{array}$ \\
\hline $\begin{array}{c}\text { Keterampilan } \\
\text { melakukan lompat } \\
\text { jauh gaya jongkok }\end{array}$ & $75 \%$ & $\begin{array}{c}\text { Diukur dari hasil tes lompat jauh gaya jongkok } \\
\text { dan dihitung dari jumlah siswa yang dapat } \\
\text { melakukan lompat jauh gaya jongkok. }\end{array}$ \\
\hline
\end{tabular}

\section{Prosedur Penelitian}

Penelitian ini menggunakan metode Penelitian Tindakan Kelas yang terdiri dari 2 siklus, langkahlangkah dalam siklus penelitian tindakan kelas menurut Kuswaya (2006) terdiri dari empat komponen, yaitu: 1) rencana, 2) tindakan, 3) observasi, 4) refleksi. Untuk lebih jelas lihat gambar dibawah ini:

\section{Gambar 3.1. Prosedur Penelitian} Tindakan Kelas

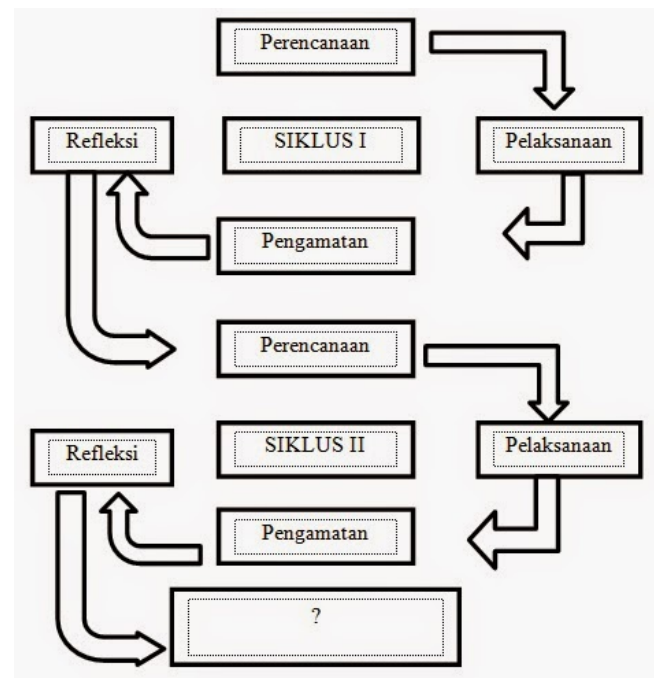

\section{SIKLUS I}

a. Perencanaan

Perencanaan tindakan meliputi memeriksa Rencana Pelaksanaan Pembelajaran (RPP) yang telah disusun, dibaca ulang, mencermati setiap butir yang akan direncanakan.

Peneliti mempersiapkan kelengkapan dan ketersediaan alat pengumpul data atau instrumen penelitian. Instrumen penelitian adalah alat atau fasilitas yang digunakan oleh peneliti dalam mengumpulkan data agar pekerjaannya lebih mudah dan hasilnya lebih baik, dalam arti cepat, lengkap, dan sistematis sehingga lebih mudah diolah (Arikunto: 2006). Instrumen yang disiapkan adalah lembar observasi, kemudian memeriksa alat yang akan digunakan, mencoba menggunakan alat, dan mensimulasikan hingga benar-benar yakin peragaan akan berjalan mulus.

\section{b. Pelaksanaan Tindakan \\ 1) Pendahuluan}

Peneliti menyiapkan siswa untuk berbaris menjadi tiga bersaf. Siswa dipersilahkan untuk berdoa dilanjutkan presensi. Peneliti memberikan apersepsi, motivasi, dan penjelasan tujuan pembelajaran.

Peneliti memberikan pemanasan dalam bentuk 
permainan. Caranya adalah siswa dibuat menjadi dua barisan bersaf saling membelakangi, guru memberikan istilah kepada siswa yang satu barisan dengan sebutan hijau dan yang satu barisan lagi dengan sebutan hitam. Peneliti memberi aba-aba jika salah satu barisan namanya disebutkan maka barisan yang membelakangi mengejar nama barisan yang disebutkan oleh peneliti. Kedua barisan melakukannya dengan cara engklek satu kaki dan apabila sudah ketangkap maka wajib menggendongnya ke arah tempat semula dan menunggu aba-aba dari peneliti selanjutnya.

\section{2) Kegiatan Inti}

Peneliti memberi pertanyaan kepada siswa siapa yang sudah tahu tentang loncat dan lompat. Siapa yang bisa melakukannya? Siswa melakukan loncat dan lompat sesuai dengan kemampuan masing-masing tanpa diberi penjelasan terlebih dahulu. Peneliti memberi contoh melakukan awalan lari, meloncat menolak dua kaki melewati bok kardus mendarat dua kaki kemudian melakukan awalan lari, melompat tolakan satu kaki melewati bok kardus mendarat dua kaki.

Peneliti memberikan kesempatan pada siswa untuk bertanya tentang kesulitan yang dialami. Siswa melakukan lompat jauh gaya jongkok mulai dari awalan, tolakan, saat melayang di udara, pendaratan pada bak lompat.

Peneliti bertanya kepada siswa tentang materi yang sedang dipelajari, seperti urutan cara melakukan lompat jauh gaya jongkok, siswa menjawab pertanyaan peneliti tentang urutan melakukan lompat jauh gaya jongkok.

Pengambilan data dilakukan selama pelaksanaan tindakan siklus I. Deskripsi data yang diambil setelah tindakan siklus I disajikan dalam bentuk tabel.

\section{3) Kegiatan Akhir}

Siswa dikumpulkan dengan cara duduk melingkar, guru menjelaskan tentang kesalahan-kesalahan gerakan yang dilakukan. Bernyanyi bersamasama, berdoa, bersama-sama, kemudian dibubarkan.

\section{c. Observasi}

\section{Observasi/pengamatan}

penelitian dilakukan selama tindakan siklus I berlangsung, yaitu peneliti mengamati proses pembelajaran lompat jauh gaya jongkok melalui alat bantu bok kardus pada siswa kelas V SDN 2 Laban Kecamatan Menganti Kabupaten Gresik . Peneliti melakukan penilaian melalui lembar observasi siswa dengan tujuan untuk mengetahui tingkat keberhasilan belajar siswa dalam pembelajaran lompat jauh gaya jongkok melalui alat bantu bok kardus. 


\section{d. Refleksi}

Dalam tahap ini, data yang diperoleh dianalisa dengan teliti. Dari pengamatan, diperoleh bahwa kesulitan yang dialami siswa dalam pembelajaran lompat jauh gaya jongkok melalui alat bantu bok kardus siklus I adalah pada saat siswa melakukan tolakan dan sikap badan di udara. Untuk mengatasi kesulitan tersebut, peneliti selalu memberikan contoh berulang kali kepada siswa, namun karena ada saja siswa yang tidak memperhatikan pembelajaran dan bermain sendiri sehingga pembelajaran kurang berhasil.

Untuk mengatasi kesulitan di atas, peneliti merencanakan tindakan selanjutnya pada siklus II.

\section{SIKLUS II}

a. Perencanaan

\section{Pelaksanaan}

kegiatan perbaikan pembelajaran siklus II menggunakan alat bantu gawang aman. Sebelum melaksanakan tindakan perbaikan, peneliti memeriksa Rencana Pelaksanaan Pembelajaran (RPP) yang telah disusun, dibaca ulang, mencermati setiap butir yang akan direncanakan sebagai perbaikan dari siklus II.

$$
\text { Peneliti mempersiapkan }
$$

kelengkapan dan ketersediaan alat pengumpul data, seperti lembar observasi, kemudian memeriksa alat yang akan digunakan, mencoba menggunakan alat, dan mensimulasikan hingga benar-benar yakin peragaan akan berjalan mulus. b. Pelaksanaan Tindakan

1) Pendahuluan

Peneliti menyiapkan siswa untuk berbaris menjadi tiga bersaf. Siswa dipersilahkan untuk berdoa dilanjutkan untuk presensi dengan tertib. Peneliti memberikan apersepsi, motivasi, dan penjelasan tujuan pembelajaran

Peneliti memberikan pemanasan dalam bentuk permainan. Caranya adalah siswa dibuat menjadi dua barisan bersaf saling membelakangi, guru memberikan istilah kepada siswa yang satu barisan dengan sebutan hijau dan yang satu barisan lagi dengan sebutan hitam. Peneliti memberi aba-aba jika salah satu barisan namanya disebutkan maka barisan yang membelakangi mengejar nama barisan yang disebutkan oleh guru. Kedua barisan melakukannya dengan cara engklek satu kaki dan apabila sudah ketangkap maka wajib menggendongnya ke arah tempat semula dan menunggu aba-aba dari guru selanjutnya.

2) Kegiatan Inti

Peneliti memberi pertanyaan kepada siswa siapa yang sudah tahu tentang loncat dan lompat. Siapa yang bisa melakukannya? Siswa melakukan loncat dan lompat sesuai dengan kemampuan masing-masing tanpa diberi penjelasan terlebih dahulu. 
Peneliti memberi contoh cara melakukan awalan lari, meloncat menolak dua kaki melewati gawang aman mendarat dua kaki. Peneliti memberi contoh gerakan melakukan awalan lari, melompat tolakan satu kaki melewati gawang aman mendarat dua kaki.

Peneliti memberikan kesempatan pada siswa untuk bertanya tentang kesulitan yang dialami. Siswa melakukan lompat jauh gaya jongkok mulai dari awalan, tolakan, saat melayang di udara, pendaratan pada bak lompat.

Peneliti bertanya kepada siswa tentang materi yang sedang dipelajari, seperti urutan cara melakukan lompat jauh gaya jongkok, siswa menjawab pertanyaan peneliti tentang urutan melakukan lompat jauh gaya jongkok.

3) Kegiatan Akhir

Siswa dikumpulkan dengan cara duduk melingkar, guru menjelaskan tentang kesalahan-kesalahan gerakan yang dilakukan. Bernyanyi bersamasama, berdoa, bersama-sama, kemudian dibubarkan.

\section{c. Observasi}

Pelaksanaan kegiatan pembelajaran lompat jauh gaya jongkok melalui alat bantu gawang aman berjalan lancar, suasana pembelajaran sangat kondusif dan siswa terlihat bersemangat. Proses pembelajaran, mulai dari pemanasan sampai dengan gerakan lompat jauh pada bak lompat diikuti siswa dengan sungguh-sungguh.

Untuk mencatat segala aktivitas pembelajaran, peneliti menggunakan lembar observasi. Dari lembar observasi diperoleh data tentang keaktifan siswa dan keefektifan alat bantu gawang aman dalam pembelajaran lompat jauh gaya jongkok siswa kelas V SDN 2 Laban Kecamatan Menganti Kabupaten Gresik .

Penggunaan alat bantu gawang aman dalam pembelajaran lompat jauh gaya jongkok dapat meningkatkan keaktifan, motivasi, dan hasil belajar siswa pada siklus II.

\section{d. Refleksi}

Pembelajaran lompat jauh gaya jongkok melalui penggunaan alat bantu gawang aman telah berjalan sesuai dengan rencana pembelajaran yang dibuat sebelumnya. Alat bantu gawang aman yang digunakan oleh peneliti mampu menarik perhatian siswa, sehingga pembelajaran berlangsung secara maksimal.

Hasil belajar siswa siklus II telah menunjukkan peningkatan sesuai dengan apa yang ditargetkan. Hasil belajar siswa pada siklus II menunjukkan bahwa seluruh siswa yang berjumlah 15 anak (100\%) telah mencapai nilai Kriteria Ketuntasan Minimal (KKM). Berdasarkan hasil tersebut disimpulkan bahwa hasil belajar lompat jauh gaya jongkok siswa melalui penggunaan alat bantu 
gawang aman telah mencapai kategori sangat baik.

Kelebihan dan keberhasilan tindakan siklus II akan dipertahankan dan berupaya untuk meningkatkan. Untuk memperbaiki kelemahan dan kekurangan tindakan siklus II, antisipasinya adalah peneliti memberikan motivasi yang lebih dan melakukan pendekatan personal kepada siswa, agar tetap berkonsentrasi dan memperhatikan pembelajaran, sehingga tujuan dapat tercapai.

\section{HASIL DAN PEMBAHASAN}

\section{Hasil Penelitian}

Kegiatan pratindakan dilakukan
sebelum pelaksanaan proses penelitian tindakan kelas berlangsung yang dimaksudkan untuk mengetahui keadaan sebenarnya tentang kondisi pembelajaran lompat jauh gaya jongkok siswa kelas V SDN 2 Laban Kecamatan Menganti Kabupaten Gresik Kecamatan Kabupaten Tahun Pelajaran 2017/2018 yang berjumlah 15 siswa yang terdiri dari 10 siswa laki-laki dan 15 siswa perempuan. Hasil belajar yang diperoleh pada kegiatan pratindakan pembelajaran lompat jauh gaya jongkok masih sangat rendah.

Perhatian siswa tidak terfokus pada pembelajaran, terutama pada saat guru menyampaikan materi, hal itu disebabkan oleh karena guru belum menggunakan metode pembelajaran yang tepat dalam materi lompat jauh gaya jongkok.
Informasi hasil wawancara menunjukkan bahwa siswa kesulitan dan kurang tertarik dalam menerima materi pembelajaran. Hal ini terbukti saat dilakukan pengamatan langsung di lapangan. Siswa terlihat acuh dan bermain sendiri ketika pembelajaran, bahkan ada beberapa siswa yang tetap asik berbicara dengan teman ketika guru menyampaikan materi. Sebagian siswa merasa takut dan canggung ketika guru memberikan materi, sehingga mereka kurang dapat memahami apa yang disampaikan oleh guru.

Tabel 2. Deskripsi Data Hasil Belajar Pratindakan

\begin{tabular}{|c|c|c|c|}
\hline No & Kriteria & $\begin{array}{c}\text { Jumlah } \\
\text { Anak }\end{array}$ & Prosentase \\
\hline 1 & Tuntas & 15 & $33,3 \%$ \\
\hline 2 & Belum tuntas & 10 & $66,7 \%$ \\
\hline \multicolumn{2}{|c|}{ JUMLAH } & $\mathbf{2 5}$ & $\mathbf{1 0 0 \%}$ \\
\hline \multicolumn{2}{|c|}{ Hasil penilaian pratindakan }
\end{tabular}

terhadap pembelajaran lompat jauh gaya jongkok siswa masih rendah, hanya 15 siswa (33,3\%) yang telah mampu melakukan lompat jauh gaya jongkok dengan benar.

Melalui deskripsi data awal, masing-masing aspek menunjukkan kriteria keberhasilan pembelajaran yang kurang, maka disusun sebuah tindakan untuk meningkatkan hasil belajar lompat jauh gaya jongkok siswa kelas $V$ SDN 2 Laban Kecamatan Menganti Kabupaten Gresik dengan menggunakan alat bantu pembelajaran. Pelaksanaan tindakan dilakukan dengan 2 siklus, 
yaitu perencanaan, pelaksanaan tindakan, observasi, dan refleksi.

\section{Deskripsi Hasil Tindakan Tiap Siklus} Siklus I

Pembelajaran lompat jauh gaya jongkok pada siklus I menggunakan alat bantu pembelajaran. Siswa mengikuti pembelajaran lompat jauh gaya jongkok dengan menggunakan alat bantu berupa bok kardus. Hasil penelitian siklus I sebagai berikut:

Tabel 3. Deskripsi Data Hasil Belajar Siklus I

\begin{tabular}{|c|c|c|c|}
\hline No & Kriteria & $\begin{array}{c}\text { Jumlah } \\
\text { Anak }\end{array}$ & Prosentase \\
\hline 1 & Tuntas & 10 & $66,7 \%$ \\
\hline 2 & Belum tuntas & 15 & $33,3 \%$ \\
\hline JUMLAH & $\mathbf{2 5}$ & $\mathbf{1 0 0} \%$ \\
\hline
\end{tabular}

Berdasarkan hasil deskripsi data siklus I, hasil lompat jauh gaya jongkok melalui alat bantu bok kardus siswa kelas V SDN 2 Laban Kecamatan Menganti Kabupaten Gresik adalah sebanyak 10 siswa $(66,7 \%)$ telah mencapai KKM dan sisanya 15 siswa (33,3\%) belum mencapai KKM.

Observasi/pengamatan

penelitian dilakukan selama tindakan siklus I berlangsung, yaitu peneliti mengamati proses pembelajaran lompat jauh gaya jongkok melalui alat bantu bok kardus pada siswa kelas V SDN 2 Laban Kecamatan Menganti Kabupaten Gresik . Peneliti melakukan penilaian melalui lembar observasi siswa dengan tujuan untuk mengetahui tingkat keberhasilan belajar siswa dalam pembelajaran lompat jauh gaya jongkok melalui alat bantu bok kardus.

Berdasarkan hasil pengamatan terhadap proses pembelajaran diperoleh gambaran tentang hasil belajar siswa, yaitu sebanyak 10 siswa $(66,7 \%)$ telah mencapai KKM dan sisanya 15 siswa $(33,3 \%)$ belum mencapai KKM.

Dalam melaksanakan tindakan siklus I terdapat kelebihan yang dapat digunakan sebagai tolok ukur keberhasilan pelaksanaan tindakan siklus I, yaitu bahwa siswa tidak merasa takut karena pembelajaran lompat jauh gaya jongkok melalui alat bantu bok kardus dapat dilakukan dengan mudah.

Di samping kelebihan, pelaksanaan tindakan siklus satu juga terdapat kelemahan, yaitu masih banyak siswa yang belum dapat melakukan lompat jauh gaya jongkok melalui alat bantu bok kardus dengan benar, masih ada siswa yang bercanda dengan tutor sebaya karena mereka adalah teman, sehingga pembelajaran terganggu. Kesulitan yang dialami siswa dalam pembelajaran lompat jauh gaya jongkok melalui alat bantu bok kardus siklus I adalah pada saat siswa melakukan tolakan dan sikap badan di udara. Untuk mengatasi kesulitan tersebut, peneliti selalu memberikan contoh berulang kali kepada siswa, namun karena ada saja siswa yang tidak memperhatikan pembelajaran 
dan bermain sendiri sehingga pembelajaran kurang berhasil. Untuk mengatasi kesulitan di atas, peneliti merencanakan tindakan selanjutnya dengan menggunakan alat bantu yang berbeda agar siswa tidak merasa bosan, alat bantu tersebut adalah gawang aman.

\section{Siklus II}

Pembelajaran lompat jauh gaya jongkok pada siklus II merupakan tindakan lanjutan dari siklus I yang dirancang untuk memperbaiki hasil belajar dan kondisi pembelajaran siklus I. Pada siklus II ini siswa mengikuti pembelajaran lompat jauh gaya jongkok dengan menggunakan alat bantu berupa gawang aman.

Pengambilan data dilakukan selama pelaksanaan tindakan siklus II. Deskripsi data yang diambil setelah tindakan siklus II disajikan dalam bentuk tabel sebagai berikut:

Tabel 4. Deskripsi Data Hasil Belajar Siklus II

\begin{tabular}{|c|c|c|c|}
\hline No & Kriteria & $\begin{array}{c}\text { Jumlah } \\
\text { Anak }\end{array}$ & Prosentase \\
\hline 1 & Tuntas & 15 & $100 \%$ \\
\hline 2 & $\begin{array}{c}\text { Belum } \\
\text { tuntas }\end{array}$ & 10 & $0 \%$ \\
\hline \multicolumn{2}{|c|}{ JUMLAH } & $\mathbf{2 5}$ & $\mathbf{1 0 0 \%}$ \\
\hline
\end{tabular}

Berdasarkan hasil deskripsi data siklus II, hasil lompat jauh gaya jongkok melalui alat bantu gawang aman siswa kelas V SDN 2 Laban Kecamatan Menganti Kabupaten Gresik adalah seluruh siswa yang berjumlah 15 anak (100\%) telah mencapai KKM, sehingga pembelajaran siklus II ini dinyatakan telah berhasil.

Pelaksanaan kegiatan pembelajaran lompat jauh gaya jongkok melalui alat bantu gawang aman berjalan lancar, suasana pembelajaran sangat kondusif dan siswa terlihat bersemangat. Proses pembelajaran, mulai dari pemanasan sampai dengan gerakan lompat jauh pada bak lompat diikuti siswa dengan sungguh-sungguh.

Untuk mencatat segala aktivitas pembelajaran, peneliti menggunakan lembar observasi. Dari lembar observasi diperoleh data tentang keaktifan siswa dan keefektifan alat bantu gawang aman dalam pembelajaran lompat jauh gaya jongkok siswa kelas V SDN 2 Laban Kecamatan Menganti Kabupaten Gresik. Penggunaan alat bantu gawang aman dalam pembelajaran lompat jauh gaya jongkok dapat meningkatkan keaktifan, motivasi, dan hasil belajar siswa pada siklus II.

Pembelajaran lompat jauh gaya jongkok melalui penggunaan alat bantu gawang aman telah berjalan sesuai dengan rencana yang dibuat. Alat bantu gawang aman yang digunakan oleh peneliti mampu menarik perhatian siswa, sehingga pembelajaran berlangsung secara maksimal.

Hasil belajar siklus II telah menunjukkan peningkatan sesuai dengan apa yang ditargetkan, yaitu 
seluruh siswa yang berjumlah 15 anak (100\%) telah mencapai nilai KKM. Berdasarkan hasil tersebut disimpulkan bahwa hasil belajar lompat jauh gaya jongkok siswa melalui penggunaan alat bantu gawang aman telah mencapai kategori sangat baik.

Kelebihan dan keberhasilan tindakan siklus II akan dipertahankan dan berupaya untuk meningkatkan. Untuk memperbaiki kelemahan dan kekurangan tindakan siklus II, antisipasinya adalah peneliti memberikan motivasi yang lebih dan melakukan pendekatan personal kepada siswa, agar tetap berkonsentrasi dan memperhatikan pembelajaran, sehingga tujuan dapat tercapai.

\section{Perbandingan Hasil Tindakan Antarsiklus}

Pelaksanaan

tindakan perbaikan pembelajaran lompat jauh gaya jongkok dari pratindakan, siklus I, dan siklus II melalui penggunaan alat bantu gawang aman diketahui dari masing-masing tindakan telah mengalami peningkatan hasil belajar lompat jauh gaya jongkok siswa kelas V SDN 2 Laban Kecamatan Menganti Kabupaten Gresik Kecamatan Kabupaten Tahun Pelajaran 2017/2018.

Selama proses pembelajaran siswa terlihat aktif dan antusias, sehingga pembelajaran berlangsung kondusif, sehingga hasil belajar sesuai dengan yang telah ditargetkan. Perbandingan hasil yang diperoleh selama proses tindakan dijabarkan dalam bentuk tabel sebagai berikut:

Tabel 5. Perbandingan Hasil Belajar Pratindakan, Siklus I, dan Siklus II

\begin{tabular}{|c|c|c|c|c|}
\hline No & Kriteria & Pratindakan & $\begin{array}{c}\text { Siklus } \\
\text { I }\end{array}$ & $\begin{array}{c}\text { Siklus } \\
\text { II }\end{array}$ \\
\hline 1 & Tuntas & $33,3 \%$ & $66,7 \%$ & $100 \%$ \\
\hline $\mathbf{2}$ & $\begin{array}{c}\text { Belum } \\
\text { tuntas }\end{array}$ & $66,7 \%$ & $33,3 \%$ & $0 \%$ \\
\hline \multicolumn{2}{|c|}{ JUMLAH } & $\mathbf{1 0 0 \%}$ & $\mathbf{1 0 0 \%}$ & $\mathbf{1 0 0 \%}$ \\
\hline
\end{tabular}

Data pada tabel 4.3. menunjukkan adanya peningkatan hasil belajar tiap siklusnya. Pada kegiatan pratindakan Persentase ketuntasan siswa baru mencapai $33,3 \%$ saja, setelah dilakukan kegiatan siklus I hasil ketuntasan belajar siswa meningkat menjadi $66,7 \%$, kemudian pada kegiatan pembelajaran siklus II, seluruh siswa (100\%) telah tuntas belajar, ini menunjukkan bahwa penggunaan alat bantu gawang aman pada pembelajaran lompat jauh gaya jongkok dapat membantu meningkatkan keaktifan dan motivasi siswa sehingga hasil belajar meningkat dan mencapai tingkat ketuntasan yang diharapkan.

Di samping hasil belajar, fokus dan keaktifan siswa juga meningkat, siswa terfokus pada pembelajaran, seluruh siswa juga telah aktif mengikuti pembelajaran, mereka terlihat antusias mengikuti pembelajaran. 


\section{Pembahasan}

Pelaksanaan

tindakan

perbaikan pembelajaran melalui penelitian tindakan kelas pada materi lompat jauh gaya jongkok melalui penggunaan alat bantu bok kardus dan gawang aman telah dapat meningkatkan keaktifan dan semangat belajar siswa sehingga tujuan perbaikan tercapai dengan optimal.

Penggunaan penggunaan alat bantu bok kardus dan gawang aman terbukti sangat membantu peningkatan hasil belajar siswa hal ini dikarenakan kelebihan penggunaan penggunaan alat bantu bok kardus dan gawang aman banyak memberikan keuntungan di antaranya siswa yang takut melakukan lompatan menjadi tidak takut. Siswa belajar dengan penuh percaya diri, semangat, disiplin, jujur, dan penuh tanggung jawab.

Peningkatan hasil belajar siswa dapat dilihat dari tabel-tabel yang telah disajikan, yaitu pada pratindakan, siswa yang telah mencapai nilai KKM 5 anak $(33,3 \%)$ dan sisanya 10 anak belum mencapai nilai KKM. Pada siklus I siswa yang telah mencapai nilai KKM 10 anak $(66,7 \%)$ dan sisanya 5 anak belum mencapai nilai KKM. Pada siklus II seluruh siswa yang berjumlah 15 anak (100\%) telah mencapai nilai KKM. Dari pratindakan ke siklus I jika dibandingkan terlihat hasil belajar siswa mengalami kenaikan 5 anak $(33,3 \%)$, yaitu dari 15 siswa menjadi
10 siswa dan dari siklus I ke siklus II juga mengalami kenaikan 5 anak (33,3\%), yaitu dari 10 siswa menjadi 15 siswa.

\section{KESIMPULAN}

Kesimpulan penelitian ini adalah pembelajaran lompat jauh gaya jongkok melalui penggunaan alat bantu dapat meningkatkan fokus dan keaktifan siswa serta suasana pembelajaran yang menyenangkan, sehingga pada akhirnya dapat meningkatkan hasil belajar siswa.

Penelitian ini berimplikasi bagi perkembangan pembelajaran pendidikan jasmani dan olahraga kesehatan di SDN 2 Laban Kecamatan Menganti Kabupaten Gresik . Guru pendidikan jasmani dan olahraga kesehatan dapat menerapkan pembelajaran atletik lompat jauh gaya jongkok melalui penggunaan alat bantu. Penggunaan alat bantu dapat pula digunakan pada materi pembelajaran pendidikan jasmani dan olahraga kesehatan lainnya, terutama pada cabang atletik, sehingga siswa merasa tertarik dengan pembelajaran yang menyenangkan sehingga tujuan akhirnya adalah dapat meningkatkan hasil belajar siswa.

\section{DAFTAR PUSTAKA}

Alwasilah, A. Chaedar. 2008. Filsafat Bahasa dan Pendidikan. Bandung: PT. Remaja. Rosdakarya 
Arikunto, Suharsimi. 2006.

Prosedur Penelitian Suatu

Pendekatan Praktek. Jakarta:

PT Rineka Cipta.

Kuswaya, Wihardit. 2006. Penelitian

Tindakan Kelas. Jakarta:

Universitas Terbuka

Rochiati, Wiriatmaja. 2005. Metode Penelitian Tindakan Kelas.

Bandung : PT.Remaja

Rosdakarya.

Sarayin. BA. 1998. Penuntun

Pelajaran Orkes Kelas I SMA.

Bandung: Ganeca Exact

Sugiyono. 2010. Metode Penelitian Pendidikan Pendekatan

Kuantitatif, kualitatif, dan R\&D.

Bandung: Alfabeta. 